\title{
The ResPonsibility to Protect: A 'Just' \\ INTERVENTION?
}

\section{Emma McClean}

\section{INTRODUCTION}

In the 2004 Report, A More Secure World, the High-Level Panel on Threats, Challenges and Change (HLP) championed 'a collective international responsibility to protect' as a key component of its vision for the United Nations (UN) collective security system. ${ }^{1}$ In doing so the HLP revived the responsibility to protect which had languished on the international stage, a casualty of the 'war on terror', since its inception in 2001 by the International Commission on Intervention and State Sovereignty (ICISS). Indeed $A$ More Secure World provided the platform for the endorsement of the responsibility to protect 'populations from genocide, war crimes, ethnic cleansing and crimes against humanity' by the UN General Assembly (GA) at the 2005 World Summit which was subsequently endorsed by the UN Security Council (SC). ${ }^{2}$ However the guidelines for military intervention for human protection purposes, a central facet of the responsibility to protect, are conspicuously absent from these endorsements.

This article charts the articulation of the responsibility to protect at the UN and examines the guidelines for military intervention for human protection purposes proposed by the ICISS and HLP within the framework of the just war tradition. It is argued that the disappearance of the guidelines from the responsibility to protect framework adopted by the UN undermines the capacity of the UN to effectively respond to genocide, war crimes, ethnic cleansing and crimes against humanity. Moreover, the just war tradition offers a fruitful frame of analysis that addresses the arguments that prompted the removal of the guidelines for military intervention from the responsibility to protect framework. It also reveals the potentially central role for international law in the authorisation and regulation of military force for human protection purposes. As such, the article proceeds in three parts the first of which charts the translation of the

\footnotetext{
${ }^{1}$ HLP, A More Secure World: Our shared responsibility (UN 2004) para. 203.

${ }^{2}$ GA Res 60/1, 'Outcome Document' (2005), paras. 138 and 139; SC Res 1674 (2006) para. 4.
} 
responsibility 'from document to doctrine's at the UN with specific reference to the guidelines for military intervention for human protection purposes before moving to explore the roles for the SC and UN peace operations envisioned under the guidelines in Parts II and III respectively, with the crisis in Darfur serving as a reference point.

\section{LOST IN Translation: ThE GUIDElines FOR MiLitary INTERVENTION}

The responsibility to protect is the progeny of ICISS and in essence means:

sovereign states have a responsibility to protect their own citizens from avoidable catastrophe . . but that when they are unwilling or unable to do so, that responsibility must be borne by the broader community of states ${ }^{4}$

Thus the responsibility to protect lies first and foremost with the state and a secondary responsibility to protect falls to the 'broader community of states' when the state is unwilling or unable to halt or avert serious harm befalling a population. A fundamental facet of the responsibility to protect, as articulated by the ICISS, is the idea of a 'continuum of obligations, ${ }^{5}$, that is the idea that the responsibility to protect consists of three dimensions - the responsibility to prevent, the responsibility to react and the responsibility to rebuild. Nonetheless the responsibility to react has been the focus of academic commentary, in particular the guidelines for military intervention for human protection purposes. These guidelines - right intention, right authority, just cause, last resort, proportional means and reasonable prospects - determine when, how and by whom the responsibility to react is be exercised and garnered plaudits such as 'the most sophisticated attempt at establishing a moral guideline for international action in the face of humanitarian emergency'. ${ }^{6}$

Indeed the HLP, which firmly placed the responsibility to protect on the international agenda by championing it as pivotal pillar in its vision of comprehensive collective security, while acknowledging that the responsibility to protect spans a 'continuum involving prevention, response to violence, if necessary, and rebuilding shattered

\footnotetext{
${ }^{3}$ Rebecca Hamilton. 'The Responsibility to Protect: From document to doctrine - but what of implementation?’ (2006) 19 Harvard Human Rights Journal 289.

${ }^{4}$ ICISS, The Responsibility to Protect (International Development Research Centre 2001) viii.

${ }^{5}$ Gareth Evans, 'From Humanitarian Intervention to the Responsibility to Protect', (2006) 24

Wisconsin International Law Journal 703, 709.

${ }^{6}$ Graham Day and Christopher Freeman, 'Operationalising the Responsibility to Protect - the

Policekeeping Approach’ (2005) 11 Global Governance 139, 139
} 
societies ${ }^{7}$ focused on the responsibility to react. The HLP set out guidelines for military intervention for human protection purposes akin to the ICISS - seriousness of threat, proper purpose, last resort, proportional means and balance of consequences. For instance for the ICISS just cause includes 'large-scale loss of life' and 'large-scale ethnic cleansing' while the HLP included 'genocide and other large scale killing' under 'seriousness of threat'. ${ }^{8}$ Further both saw the use of military force as a last resort which must have a 'reasonable chance' of success and be proportionate to the humanitarian objective to be achieved, that is the 'proper purpose' or 'right intention'. Moreover, the ICISS etched out a role for the SC in exercising the responsibility to react under the criterion of 'right authority' while the HLP similarly envisioned the SC as exercising the responsibility to react. In doing so, the ICISS and the HLP acknowledged the institutional obstacles, such as the privileged position of the P-5, including the veto, along with galvanising the necessary political will, facing the SC in the exercise of the responsibility to react. However it was the HLP that addressed these obstacles facing the SC by putting forward proposals for the reform of the SC. The HLP also discussed the role of UN peace operations recognising, as did the ICISS, that a "clear and unambiguous mandate is one of the first and most important requirements of an operation to protect' ${ }^{9}$ along with stressing the importance of securing 'the necessary resources to implement that mandate fully'. ${ }^{10}$

The then SG, Kofi Annan, endorsed the 'more comprehensive concept of collective security' envisioned by the HLP in his 2005 Report, In Larger Freedom, including the responsibility to protect and the proposals for SC reform. However, as Alex J. Bellamy observes, the responsibility to protect was diluted in the transition from A More Secure World to In Larger Freedom. Of particular note was the separation of the guidelines for military intervention from the endorsement of the responsibility to protect - a divorce that seemingly facilitated the endorsement of the responsibility to protect in principle by UN member states at the 2005 World Summit. ${ }^{11}$ Here world leaders declared themselves prepared:

\footnotetext{
${ }^{7}$ HLP (n 1) para. 201

${ }^{8}$ ICISS (n 4) para. 32-34; HLP (n 1) para 207 (a).

${ }^{9}$ ICISS (n 4) para. 60; HLP(n 1) para 214.

${ }^{10}$ ICISS (n 4) para 60; HLP (n 1) para 214.

${ }^{11}$ See Alex J. Bellamy, 'Whither the Responsibility to Protect? Humanitarian Intervention and the 2005 World Summit' (2006) Ethics and International Affairs 143, 166.
} 
[t]o take collective action, in a timely and decisive manner, through the Security Council, in accordance with the Charter, including Chapter VII, on a case-bycase basis . . . should peaceful means be inadequate and national authorities are manifestly failing to protect their populations from genocide, war crimes, ethnic cleansing and crimes against humanity ${ }^{12}$

The 'case-by-case basis' by which this responsibility to react is to be exercised by the $\mathrm{SC}$ is underscored by the absence of guidelines for military intervention in the Outcome Document and exacerbated by the commitment to merely continue to discuss SC reform. ${ }^{13}$ Indeed the US specifically referred to the preservation of SC discretion when opposing the inclusion of the guidelines while Russia and China, along with some developing countries, rejected the guidelines for military intervention for human protection purposes, albeit on non-interventionist grounds. For instance, developing countries saw the guidelines as a 'Trojan-horse', arguing that the possibility of abuse that permeates such guidelines precludes their adoption. Moreover, while France and the UK were receptive to the guidelines for military intervention for human protection purposes, they voiced concerns as to the capacity of guidelines to galvanise the SC to act. $^{14}$

These shortcomings are assimilated and consolidated in the recent Report by the SG, Ban Ki Moon, 'Implementing the Responsibility to Protect'. ${ }^{15}$ This is unsurprising as the Report is based on the 'authoritative framework' of the Outcome Document. ${ }^{16}$ Thus while the Report acknowledges the 'hard truth that no strategy for fulfilling the responsibility to protect would be complete without the possibility of enforcement measures, including through sanctions or coercive military action in extreme cases', it merely suggests that the SC or the GA could authorise such collective measures. ${ }^{17}$ This acknowledgement does little to temper Bellamy's indictment that the responsibility to protect, as found in the Outcome Document and thus in the SG's report, 'does little to prevent future Rwandas and Kosovos', ${ }^{18}$ which to too readily evident in the 'glacial speed ${ }^{19}$ at which the UN has responded to the crisis in Darfur. Indeed the response to

\footnotetext{
${ }^{12}$ Outcome Document (n 2) para. 139 (emphasis added)

${ }^{13}$ Ibid para 153.

${ }^{14}$ Bellamy, 'Whither' (n 11) 167.

${ }^{15} \mathrm{SG}$, 'Implementing the Responsibility to Protect' (12 January 2009).

${ }^{16}$ Ibid para 2.

${ }^{17}$ Ibid para 56.

${ }^{18}$ Bellamy, 'Whither' (n 11), 146.

${ }^{19}$ HLP (n 1) para 42.
} 
the crisis in Darfur not only underscores the practical imperative for guidelines for military intervention for human protection purposes but also demands an assessment of the veracity of the arguments that ensured their removal from the responsibility to protect framework, particularly as the UN, including the SC, has accepted the responsibility to protect populations from genocide, war crimes, ethnic cleansing and crimes against humanity. Indeed the arguments of SC discretion, and the possibility of abuse and securing the necessary political will and consensus to act imbued the debate on the responsibility to protect at the 2005 World Summit. These arguments, together with the unsettled legal status of this principle, have mired this 'inconclusive debate' on humanitarian intervention. ${ }^{20}$ The responsibility to react, including guidelines for military intervention, is not yet an established legal norm. Moreover, these proposed guidelines do not yet provide a justificatory and enabling framework determining when, how and by whom the responsibility to react is exercised. As such, it is proposed to draw upon the just war tradition which, as a "two-thousand year old conversation about the legitimacy of war' ${ }^{21}$, 'encompasses many of the arguments' ${ }^{22}$ that revolve around the guidelines for military intervention for human protection purposes in order to identify and develop the legal and normative framework for the roles for the SC and UN peace operations under the responsibility to react.

\section{Galvanising The UN Security Council}

The guidelines for military intervention for human protection purposes espoused by the ICISS and the HLP invoke the just war tradition, particularly the criteria governing the resort to war. ${ }^{23}$ Indeed there are important points of correlation between the guidelines and these just war norms, not in the least that both purport to govern the resort to military force. Furthermore, while disagreement abounds as the 'interpretation ... and relative weight' ${ }^{24}$ to be accorded to the jus ad bellum criteria and thus 'not all contemporary just war theorists offer the same list ${ }^{25}$, there is a broad consensus within the just war tradition as to the 'common set of rules governing the decision to wage

\footnotetext{
${ }^{20}$ Louise Arbour, 'The Responsibility to Protect as a Duty of Care in International Law and Practice' (2008) 34 Review of International Studies 445, 447.

${ }^{21}$ Bellamy, Just Wars: From Cicero to Iraq (Polity 2006) 4.

${ }^{22}$ Mona Fixdal and Dan Smith, 'Humanitarian Intervention and Just War' (1993) 42 Mershon International Studies Review 283.

${ }^{23}$ Thomas G. Weiss remarks that the ICISS proposed 'a modified just war doctrine for future interventions'. Thomas G. Weiss, Humanitarian Intervention: Ideas in Action (Polity 2007) 111.

${ }^{24}$ Bellamy, Just War (n 21) 4.

${ }^{25}$ Michael Bough et al, Rethinking the Just War Tradition (SNUY Press 2007) 244.
} 
war $^{26}$, namely right authority, just cause, right intention, last resort, proportional means, and reasonable prospects of success. As such, for the present purpose of assessing the guidelines for military intervention for human protection purposes within a just war framework, little significance is attached to the slightly different taxonomies offered by the ICISS and the HLP.

This Part draws on the just war tradition to explore the role for the SC in exercising the responsibility to react envisioned by the ICISS and the HLP by way of reference to the criteria of right authority, just cause and right intention, and places these criteria within the legal landscape of the international legal regulation of the use of force, the jus ad bellum.

\section{A. Right Authority}

There are two exceptions to the prohibition on the use of force found in Article 2 (4) of the UN Charter, namely the use of force in self-defence and the use of force pursuant to SC authorisation, upon an Article 39 determination that a 'threat to the peace, breach of the peace, or act of aggression has occurred'. Seen in this light the role accorded to the SC in exercising the responsibility to react by the ICISS and the HLP appears to satisfy the requirement of right authority with relative ease. Indeed the ICISS noted that the SC is the most 'appropriate body . . . to deal with military intervention issues for human protection purposes' precisely because it has the legal capacity. ${ }^{27}$ Nonetheless the criterion of right authority, as understood in the just war tradition, also entails consideration of the more nebulous issue of legitimacy which involves an inquiry 'as to the breadth and depth of popular support this authority possesses'. ${ }^{28}$ The SC suffers from a well-documented legitimacy deficit ${ }^{29}$ particularly in relation to responding to genocide and ethnic cleansing which prompted the HLP to observe scathingly that ${ }^{6}[t]$ he Security Council so far has been neither very consistent nor very effective in dealing with cases, very often acting too late, too hesitantly, or not all' ${ }^{30}$ Indeed, as noted above, it was the HLP that attempted to address the legitimacy deficit by setting forth proposals for the reform of the SC.

\footnotetext{
${ }^{26}$ Bellamy, Just War (n 21) 4.

${ }^{27}$ ICISS (n 4) 49.

${ }^{28}$ James Turner Johnson, Can Modern War be Just? (Yale University Press 1984) 24.

${ }^{29}$ HLP (n 1) 246-247.

${ }^{30}$ HLP (n 1) para. 202.
} 
In brief, the HLP recommended that SC reform should take the form of enlargement and proposed two Models for expansion. Under both models membership of the SC would increase from 15 to 24 states. $^{31}$ While the focus of the HLP on enlargement is unsurprising when placed in historical context, ${ }^{32}$ the prognosis for such proposals remains unaltered namely that the UN 'has its problems, but a bigger Security Council, far from solving them, will only reduce the Council's effectiveness'. ${ }^{33}$ Indeed the HLP's emphasis on 'legitimacy in terms of the representativity of the Council's composition' rather than the 'performance legitimacy' of the $\mathrm{SC},{ }^{34}$ is all too readily illustrated by the retention of the veto powers of the P-5 under the proposed models. While the HLP explained this in terms of '[w]e see no practical way of changing the existing members' veto powers ${ }^{35}$ it was the threat of the veto, primarily by Russia and China, that stymied the initial response of the SC to the crisis in Darfur. In this respect the proposal by the HLP that the P-5 'pledge themselves to refrain from the use of the veto in cases of genocide and large-scale human rights abuses' is welcome. ${ }^{36}$ In particular the proposal intimates a connection between right authority and just cause thereby suggesting a potential way forward by which to alleviate the legitimacy deficit.

\section{B. Just Cause}

As violence erupted in Darfur in February 2003, the SC responded with 'glacial speed ${ }^{37}$ only determining in July 2004 the existence of a threat to the peace under Article 39, triggering Chapter VII enforcement measures in the form of sanctions. ${ }^{38}$ In the interim thousands of people had been killed in aerial and ground attacks ${ }^{39}$ with an estimated 200,000 people seeking refuge in neighbouring Chad. ${ }^{40}$ This is unsurprising for, as noted above, SC practice in respect of humanitarian crises such as genocide, ethnic cleansing and other incidents of mass human rights violations has been

\footnotetext{
${ }^{31}$ HLP (n 1) paras $252-253$.

${ }^{32}$ Yehuda Z. Blum, 'Proposals for UN Security Council Reform' (2005) 99 AJIL 632.

${ }^{33}$ W. Michael Reisman, 'Expanding the Security Council: Much Ado' (2005) 36 Security Dialogue $373,374$.

${ }^{34}$ David M. Malone, 'The High-Level Panel and the Security Council' (2005) 36 Security Dialogue 370, 371. David M. Malone borrows the term 'performance legitimacy' from Ramesh Thakur.

${ }^{35}$ HLP (n 1) para 256.

${ }^{36}$ Ibid.

${ }^{37}$ Ibid para. 42.

${ }^{38}$ SC Res 1556 (2004), preamublar para. 21

${ }^{39}$ Human Rights Watch, Sudan: New Darfur Documents, 19 July 2004 available at http://www.hrw.org/en/news/2004/07/19/sudan-new-darfur-documents accessed 4 March 2009.

${ }^{40}$ SC Res 1556 (2004) preamublar para. 20
} 
inconsistent. A survey of relevant SC practice revealed that humanitarian crises are not 'an autonomous issue ${ }^{41}$ for the purposes of making an Article 39 determination prompting SC enforcement action. ${ }^{42}$ Indeed what little consistency is discernible in relevant SC practice is an insistence on an international dimension to the humanitarian crisis, such as refugee flows ${ }^{43}$ and an emphasis on the 'unique character' of the crisis. ${ }^{44}$ Although this exercise of discretion is consistent with the Charter mandate of the SC 'to ensure prompt and effective action', ${ }^{45}$ the initial response of the SC to the crisis in Darfur highlights the arguments advanced by the US at the 2005 World Summit in respect of SC discretion.

It was against this backdrop of SC practice that the ICISS and the HLP promulgated 'just cause' and 'seriousness of threat' which trigger the responsibility to react. While, as noted above the ICISS and the HLP propose comparable thresholds, namely large scale loss of life, such as genocide and large scale ethnic cleansing, both succumb to a charge of indeterminacy ${ }^{46}$ which is not alleviated by the "narrow but deep 47 understanding evident in the Outcome Document, that of 'genocide, war crimes, ethnic cleansing and crimes against humanity'. Nonetheless, such formulations are compatible with SC practice and is consistent with the just war tradition. The emphasis in the just war tradition, particularly since the UN Charter, has been on self-defence as a just cause. Nonetheless 'the just war tradition contains a much richer vein of just cause', including for humanitarian purposes. ${ }^{48}$ For instance, Walzer emphatically states:

Against the enslavement or massacre of political opponents, national minorities and religious sects, there may well be no help unless help comes from outside. ${ }^{49}$

\footnotetext{
${ }^{41}$ Christian Tomuschat, Human Rights: Between Idealism and Realism (OUP Oxford 2003) 129.

${ }^{42}$ Karel Wellens, 'The UN Security Council and New Threats to the Peace: Back to the Future' (2003)

8 Journal of Conflict and Security Law 15

${ }^{43}$ For example, SC Resolution 841 spoke of the 'negative repercussions' of the refugee flows from Haiti on the region. SC Res 841 (1993) preamublar para. 9. In respect of Darfur see SC Res 1556 (2004) preamublar para. 20.

${ }^{44}$ For instance, the SC explicitly emphasised the 'unique character' of the situation in Somalia. SC Res 794 (1992) preamublar para. 2.

${ }^{45}$ Article 24, UN Charter.

${ }^{46}$ Bellamy, 'Whither' (n 14) $148-151$.

${ }^{47} \mathrm{SG}$, 'Implementing' (n 15) para. 10.

${ }^{48}$ Brough et al (n 25) 233.

${ }^{49}$ Michael Walzer, Just and Unjust Wars: A moral argument with historical illustrations $\left(4^{\text {th }}\right.$ ed Basic Books 2006) 101.
} 
Genocide, war crimes, ethnic cleansing and crimes against humanity are all defined by international law in treaties such as the Genocide Convention 1948 and the Rome Statute 1998, along with customary international law. International law thus provides a crucial ground to draw from in order to lend greater determinacy to the just cause criterion of the responsibility to react whether understood as large-scale killing and large-scale ethnic cleansing or as the tetralogy of 'genocide, war crimes, ethnic cleansing and crimes against humanity'. For example, crimes against humanity are defined in the Rome Statute as certain actions 'committed as part of a widespread or systematic attack directed against any civilian population, with knowledge of the attack $^{50}$ which includes large-scale killing without genocidal intent and ethnic cleansing and is 'to a great extent predicated upon international human rights law'. ${ }^{51}$ In a similar way, war crimes are defined as serious violations of international humanitarian law as found in customary and treaty law. ${ }^{52}$

The prohibition on genocide is widely regarded as a norm of jus cogens and genocide is defined in the Genocide Convention as the intentional destruction 'in whole or in part, a national, ethnical, racial or religious group' by killing members of the group, causing serious bodily or mental harm to members of the group, 'deliberately inflicting on the group conditions of life calculated to bring about its physical destruction in whole or in part' and forcibly transferring children of one group to another group. ${ }^{53}$ In a recent decision the International Court of Justice (ICJ) found that Serbia had violated its obligations to prevent the genocide at Srebrenica in 1995. In order to so the ICJ construed the obligation in Article I on states to prevent and punish genocide as entailing an obligation on states to refrain from engaging in genocide before holding that a failure to prevent genocide would engender state responsibility in addition to individual responsibility under the Convention. ${ }^{54}$

\footnotetext{
${ }^{50}$ Article 7, Rome Statute 1998.

${ }^{51}$ Antonio Cassese, International Criminal Law (2 $2^{\text {nd }}$ ed OUP 2008) 99.

${ }^{52}$ For example, Article 8 of the Rome Statute.

${ }^{53}$ Article II, Genocide Convention 1948; Article 6 of the Rome Statute.

${ }^{54}$ Application of the Convention on the Prevention and Punishment of the Crime of Genocide (Bosnia and Herzegovina v Serbia and Montenegro [2007] ICJ Reports paras. 163 and 173.
} 
The reluctance of the SC to accord the crisis in Darfur the status of genocide, ${ }^{55}$ demonstrates the difficulty in satisfying the just cause criterion, even in the presence of a clear and well-established legal definition. Bellamy offers an avenue to circumvent these threshold issues grounded in a relationship between right authority and just cause. In essence, the $\mathrm{SC}$ as the 'most appropriate body' ${ }^{56}$ to exercise the responsibility to react, does so under the rubric of threat to the peace 'presumably because common values have been violated'. ${ }^{57}$ As such the just cause criterion may comprise of 'many injustices below the threshold of mass killing and ethnic cleansing, ${ }^{58}$ which were stipulated by the ICISS, the HLP and reflected in the Outcome Document. In addition to circumventing the difficulties seen in respect of Darfur, this approach is also consistent with SC discretion in making Article 39 determinations. Moreover, this approach maintains a role for international law in lending a greater degree of determinacy to the just cause criterion, particularly the elements of crimes against humanity and war crimes that are predicated upon international human rights law and international humanitarian law respectively.

Furthermore, it is possible to view this 'profound connection between right authority and the just cause threshold ${ }^{59}$ from the perspective of the rule of law and more specifically, the legal constraints on SC decision-making. In recent times, the question of legal constraints on SC decision-making has been brought into sharp relief as the type of activities, such as the issue of 'quasi-legislative resolutions', undertaken by the SC has burgeoned. ${ }^{60}$ However, as Simon Chesterman observes, 'whether the rule of law applies to the UN remains unclear'. ${ }^{61}$ The argument presented here is that as the $\mathrm{SC}$ derives its discretion to exercise enforcement measures from the Charter, the

\footnotetext{
${ }^{55}$ A Commission of Inquiry was established in 2004 which concluded that, although violations of international humanitarian law and international human rights law had occurred, Sudan had not pursued a genocidal policy in respect of Darfur. Independent Commission of Inquiry on Darfur, 'Report of the Independent Commission of Inquiry on Darfur to the United Nations Secretary-General', available at http://www.un.org/News/dh/sudan/com_inq_darfur.pdf accessed 4 March 2009.

${ }^{56}$ HLP (n 1) para. 202; ICISS (n 4) 47.

${ }^{57}$ Bellamy, Just Wars (n 21) 209 (italics in original).

${ }^{58}$ Ibid 211.

${ }^{59}$ Ibid 208.

${ }^{60}$ See Simon Chesterman, 'UNaccountable? The United Nations, Emergency Powers, and the Rule of Law in Asia', New York University Public Law and Legal Theory Working Papers, available at http://lsr.nellco.org/cgi/viewcontent.cgi?article=1095\&context=nyu/plltwp accessed 4 February 2009 2.

${ }^{61}$ Ibid 2.
} 
decision whether to do so or not is subjected to legal constraints. ${ }^{62}$ The ICJ was clear in the Admissions Case that political organs, such as the SC, operate within legal parameters that act as limitations on and criteria for decision-making. ${ }^{63}$ Thus the decision whether the just cause criterion has been satisfied for the purposes of military intervention for human protection purposes is informed by international law. The task at hand, therefore, is to identify the relevant international law. In this respect, it is widely accepted that the SC is constrained by jus cogens norms such as the prohibition on genocide. ${ }^{64}$ Alexander Orakhelashvili also counts international humanitarian law as jus cogens, along with international human rights law asserting in the latter respect that the SC 'can never be entitled to infringe upon human rights embodied in universal human rights instruments' ${ }^{65}$ In this regard the Bosnian Genocide Case may prove to be instructive in that while the SC is obligated not to infringe human rights as a matter of treaty law for example, ${ }^{66}$ it may also be obligated to prevent human rights violations such as genocide and ethnic cleansing.

This formulation of the relationship between right authority and just cause demands a role for international law in SC decision-making, specifically international human rights law and international humanitarian law especially as criterion for recourse to enforcement action. Injecting the rule of law into SC decision-making in respect of the responsibility to react serves to guard against abuse with international human rights law and international humanitarian law separating 'the few sheep of legitimate humanitarianism from the herds of goats'. ${ }^{67}$ Moreover, these perspectives on the close

\footnotetext{
${ }^{62}$ Alexander Orakhelashvili, 'The Impact of Peremptory Norms on the Interpretation and the Application of United Nations Security Council Resolutions' (2005) 16 EJl 59

${ }^{63}$ The ICJ stated: 'The political character of an organ cannot release it from the observance of the treaty provisions established by the Charter when they constitute limitations on its powers or criteria for its judgment'. Conditions of Admissions of a State to Membership of the United Nations (Article 4 of the Charter) [1947-8] ICJ Rep 57, 64.

${ }^{64} \mathrm{Cf}$. Case Concerning Application of the Convention on the Prevention and Punishment of the Crime of Genocide (Bosnia and Herzegovina v Yugoslavia) [1996] ICJ Rep 595. The European Court of Justice recently declared that it can indirectly check 'the lawfulness of the resolutions of the Security Council in question with regard to jus cogens, understood as a body of higher rules of public international law binding on all subjects of international law, including the bodies of the United Nations, and from which no derogation is possible' Ahmed Ali Yusuf and Al Barakaat International Foundation $v$ Council of the European Union and Commission of the European Communities (Case T306/01) (Court of First Instance of the European Communities, 21 September 2005) available at http://curia.int, para 277.

${ }^{65}$ Orakhelashvili (n 62)

${ }^{66}$ Orakhelashvili (n 62)

${ }^{67}$ Thomas M. Franck and Nigel S. Rodley, 'After Bangladesh: The Law of Humanitarian Intervention by Military Force' (1973) 67 AJIL 275, 284.
} 
connection between right authority and just cause can be amalgamated in that the common values that the SC acts to uphold are jus cogens norms. Drawing a connection between right authority and just cause in this way, maintains SC discretion when making Article 39 determinations as to whether a threat to the peace exists triggering enforcement measures while guarding against abuse in the exercise of those powers. For, in the last analysis, these criteria for military intervention for human protection purposes galvanise the SC to act in the face of humanitarian crises such as large-scale killing and large-scale ethnic cleansing as a matter of legal obligation rather than political will which is heavily reliant on public opinion. ${ }^{68}$

\section{Right Intention}

Michael Walzer observes that:

[c]lear examples of what is called 'humanitarian intervention' are very rare. Indeed, I have not found any, but only mixed cases where the humanitarian motive is one among several. States' don't send their soldiers into other states, it seems, only in order to save lives. ${ }^{69}$

This observation underscores the imperative of the criterion of right intention in the just war tradition and speaks to the Trojan Horse arguments made by developing states at the World Summit in respect of the guidelines for military intervention for human protection purposes. However, as Bellamy emphasises, the just war tradition draws a distinction between motive and intention requiring 'that those embarking on humanitarian intervention have a primarily humanitarian intent ${ }^{70}$ which is echoed by the HLP. ${ }^{71}$ Thus the SC when authorising Chapter VII enforcement measures does so to maintain international peace and security, but it may do so with different intentions as exemplified by the diverse range of situations that fall to be considered threats to the peace under Article 39.

\footnotetext{
${ }^{68}$ In this respect Alex J. Bellamy observed 'that there is little evidence to suggest that states intervene in foreign emergencies because they are in some sense morally shamed into doing so by either domestic or global public opinion'. Bellamy 'Whither' (n 11) 150-1.

${ }^{69}$ Walzer (n 49) 101.

${ }^{70}$ Bellamy, Just Wars (n 21) 211 (italics in original).

${ }^{71}$ HLP (n 1) para. 207 (b).
} 


\section{UN Peace Operations and 'Human Protection OPERATIONS'}

The criteria of last resort, proportional means and reasonable prospects speak directly to the capacity of UN peace operations to discharge the responsibility to react. As such this Part draws on the just war tradition to explore the role for UN peace operations envisioned by the ICISS and the HLP under the responsibility to react by way of reference to last resort, proportional means and reasonable prospects, with UNAMID, the hybrid UN/African Union (AU) mission for Darfur, as a reference point. Moreover, as UNAMID has a Chapter VII mandate to use force to protect the civilian population, the Part also draws upon the aspects of jus in bello (conduct in war) that are found in international law, specifically international humanitarian law.

\section{A. Last Resort}

As the crisis situation in Darfur worsened in the months following the outbreak of violence in February 2003, the AU deployed the African Union Mission in the Sudan (AMIS), while, as noted above, the SC imposed sanctions in July $2004 .^{72}$ The following year the SC established the United Nations Mission in Sudan (UNMIS), ${ }^{73}$ and referred the situation in Darfur to the prosecutor of the International Criminal Court. ${ }^{74}$ It was this plethora of responses to the crisis that, in part, prompted the International Crisis Group (ICG) to assert that '[m] meh more still can and should be done by the international community' and ultimately to conclude that the last resort criterion for military intervention for human protection purposes in Darfur had not been fulfilled. ${ }^{75}$ Yet, during this time Human Rights Watch continued to record mass human rights violations along with increases in the numbers seeking refuge in neighbouring Chad and those internally displaced, ${ }^{76}$ while AMIS was plagued by criticisms of being underresourced and under-mandated. This disjuncture between the response to and the reality of the crisis in Darfur underscores the observation by Nicholas Wheeler that 'during

\footnotetext{
${ }^{72}$ SC Res 1554 (2004); also SC Res 1591 (2005).

${ }^{73}$ SC Res 1590 (2005)

${ }^{74}$ SC Res 1593 (2005)

${ }^{75}$ ICG, 'Getting the UN into Darfur', Africa Briefing No. 43 (12 October 2006) 17. In contrast Alex de Waal asserted that this multiplicity of responses impeded a clear and coherent strategy. Alex de Waal, 'Darfur and the Failure of the Responsibility to Protect' (2007) 83 (6) International Affairs 1039, 1043.

${ }^{76}$ Human Rights Watch, World Report 2005, available at http://hrw.org/wr2k5/wr2005.pdf accessed 7 December 2007.
} 
the time that policy-makers are trying to achieve a halt to the abuses through nonviolent means, massacres and expulsions might be continuing on the ground' ${ }^{77}$ In providing guidance as to the content of the last resort criterion the just war tradition illuminates a potential role for international law in bridging the dissonance between the response to and the reality of a humanitarian crisis, such as genocide or ethnic cleansing.

In the just war tradition the requirement of last resort is often linked to the principle of necessity as it involves a calculation that military force is 'the only feasible strategy' ${ }^{78}$ As Bellamy observes such a calculation does not 'require the exhaustion of every means short of force' 79 but rather, as the ICISS recognised, 'there must be reasonable grounds for believing that, in all the circumstances, if the measure [short of force] had been attempted it would not have succeeded' ${ }^{80}$ This understanding of last resort echoes the principle of necessity found in the international law governing the use of force in selfdefence. In international law, the necessity to use force in self-defence must be 'instant, overwhelming, leaving no choice of means, and no moment for deliberation' and, as the force is justified by necessity, it 'must be limited by that necessity and kept clearly within it'. ${ }^{81}$ This classic statement of the principle of necessity in the international law of self-defence is relatively uncontroversial. ${ }^{82}$ For instance it is generally accepted that the purpose of the use of force in self-defence is to repel an armed attack and must cease once the attack has been repelled. Thus the ICJ in Nicaragua found that as the armed opposition against El Salvador had been completely repulsed before the US had begun to take action, there was no necessity of self-defence. ${ }^{83}$ It is this connection between the necessity of self-defence and an armed attack that is instructive in determining whether the last resort criterion has been fulfilled. When considering whether it was necessary for the US to use force in self-defence, the ICJ in Nicaragua set out a scale and effects test, i.e. looked at the nature of the attacks concerned ${ }^{84}$ and did not focus on the 'likelihood that peaceful means may be effective to restore peace and remove the

\footnotetext{
${ }^{77}$ Nicholas Wheeler, Saving Strangers: Humanitarian Intervention in International Society (OUP 2000) 35 .

${ }^{78}$ Bellamy, Just War (n 21) 123.

${ }^{79}$ Ibid.

${ }^{80}$ ICISS (n 4) 36.

${ }^{81}$ The Caroline Case in David Harris, International Law: Cases and Materials

${ }^{82}$ See Oscar Schachter, International Law in Theory and Practice (Martinus Nijhoff 1991) 152.

${ }^{83}$ Military and Paramilitary Activities in and against Nicaragua (Nicaragua v US) [1986] ICJ Rep 14.

${ }^{84}$ Ibid para. 195.
} 
attackers' ${ }^{85}$ In short, in deciding whether military force for human protection purposes is the 'last resort' account must be had of the nature of the situation. This approach has the benefit of re-focusing our attention on the why of the international responsibility to react, namely to protect populations from 'genocide, war crimes, ethnic cleansing or crimes against humanity ${ }^{86}$ and lends greater determinacy to SC decision-making in authorising the use of military force for human protection purposes.

\section{B. Reasonable Prospects}

With the continuing violence highlighting the deficiencies in the responses by the UN and the AU to the crisis in Darfur, the UN and AU concentrated efforts on creating a robust UN peace operation to replace the 'beleaguered African troops' ${ }^{87}$ Despite the obfuscation of Russia and China, these efforts crystallised in SC Resolution 1706 (2006) which provided for 17,300 military personnel ${ }^{88}$ with a Chapter VII mandate to use force to, amongst others, protect the civilian population. ${ }^{89}$ However the Sudanese government refused to consent to the deployment of the proposed peace operation calling the mission 'a 'colonialist' attempt to subjugate the country'. ${ }^{90}$ A period of intense negotiation followed between the UN, the AU and the Sudanese government with SC Resolution 1769 finally passed in July 2007, with Russia and China abstaining, establishing UNAMID a hybrid UN/AU peace operation with a Chapter VII civilian protection mandate and 20,600 personnel, including 19,555 troops. ${ }^{91}$ The abstention of Russia and China, along with the reliance on the consent of Sudan, underscores the pivotal role of reasonable prospects in the guidelines for military intervention. For instance, the P-5 are automatically disqualified from military intervention for human protection proposes under the requirement of reasonable prospects. Moreover, Sudan continued to delay troop deployment with 15, 179 uniformed personnel, including 12, 359 troops deployed to the region as of 31 January $2009 .^{92}$

\footnotetext{
${ }^{85}$ Schachter (n 82) 152.

${ }^{86}$ Outcome Document (n 2) para. 139.

${ }^{87}$ Peter Kagwanja and Patrick Mutahi, 'Protection of Civilians in African peace missions: The case of the African Union Mission in Sudan, Darfur’ ISS Paper 139, May 2007, 1 available through www.issafrica.org accessed 3 March 2009.

${ }^{88}$ SC Res 1706 (2006) para. 3.

${ }^{89}$ Ibid para. 12 (a)

${ }^{90}$ Kaqwanja and Mutahi (n 87) 10

${ }^{91}$ SC Res 1769 (2007) paras 15 (a) 2.

${ }^{92}$ http://www.un.org/Depts/dpko/missions/unamid/facts.html accessed 21 February 2009.
} 
In addition to delayed troop deployment, UNAMID also faces challenges such as financing and equipment concerns, notwithstanding the Chapter VII civilian protection mandate. ${ }^{93}$ These operational and logistical challenges serve to undermine the reasonable prospects of success for UNAMID as a 'human protection operation'. Indeed James Sloan counts inadequate resources as a reason for the failure of peace operations with a Chapter VII civilian protection mandate and advocates returning to traditional peacekeeping doctrine of the use of force only in self-defence. ${ }^{94}$

\section{Proportional Means}

Proportionality infuses the just war tradition, firstly as a requirement governing the resort to war (jus ad bellum) and secondly, as a requirement governing conduct in war (jus in bello). The rationale underpinning proportionality in the just war tradition, particularly jus ad bellum, is to ensure that 'the overall harm likely to be caused by the war is less than that caused by the wrong that is being righted'. ${ }^{95}$ The HLP framed this requirement as 'are the scale, duration and intensity of the proposed military action the minimum necessary to meet the threat in question?" 96 which was answered in the affirmative by the ICG when considering whether the responsibility to react should be exercised in respect of the crisis in Darfur, as "[a]ny military intervention would be narrowly concentrated on protecting civilians and halting lawlessness and impunity in Darfur' ${ }^{97}$ In this respect it is noteworthy that SC Resolution 1769 authorises UNAMID under Chapter VII of the Charter to 'take the necessary action' to, amongst others, protect civilians. ${ }^{98}$ Thus this section assesses the role of proportionality in 'calibrating means and ends' in respect of the Chapter VII civilian protection mandate of UNAMID.

The insistence that ' $[\mathrm{t}]$ he means have to be commensurate with the ends' 99 in the guidelines for military intervention for human protection purposes accentuates the 'fundamental question as to whether violent means can ever serve humanitarian purposes'. ${ }^{100}$ The requirement that military intervention does 'more good than harm'

\footnotetext{
${ }^{93}$ See further ICG (n 75) 17.

94 James Sloan, 'The Use of Offensive Force in UN Peacekeeping: A cycle of boom and bust?' (2007)

30 Hastings International Law and Comparative Law Review 385452.

${ }^{95}$ Ibid 123.

${ }^{96}$ HLP (n 1) para. 207 (d).

${ }^{97}$ ICG (n 75) 17.

${ }^{98}$ SC Res 1769 (2007) para. 15.

${ }^{99}$ ICISS (n 4) 37.

${ }^{100}$ Wheeler (n77) 35.
} 
entails assessing the adverse humanitarian impact of military intervention against the humanitarian objective of the intervention, such as the protection of the civilian population from genocide and ethnic cleansing. Nigel S. Rodley succinctly explained this balance as: 'the gravity and extent of the violations [must] be on a level commensurate with the reasonably calculable loss of life, destruction of property [and] expenditure of resources'. ${ }^{101}$ Yet, the UN and AU when formulating the mandate for UNAMID did not undertake an in-depth field assessment of the situation in Darfur. ${ }^{102}$ This failure, in addition leaving UNAMID bereft of a concept for operations as regards its role in civilian protection, ${ }^{103}$ casts doubt on the proportionality of the military intervention in Darfur and arguably undermines the credibility of UNAMID.

Moreover the discernible trend in UN practice since the 1990's to 'bestow forceful mandates on peacekeeping operations ${ }^{104}$ is controversial not in the least because such a peace operation 'virtually always produces destructive and counterproductive results' ${ }^{105}$ This brings proportionality in the conduct of war - jus in bello - into sharp relief. As noted above jus in bello requires a proportionality assessment whereby 'military targets may only be attacked when their military value outweighs the foreseeable destruction that will result', ${ }^{106}$ along with the principle of discrimination or non-combatant immunity and the non-use of prohibited weapons. These jus in bello requirements are embodied in international humanitarian law which, for example, speaks of non-combatant immunity in addition to protecting civilians from the consequences of war and ensuring the provision of or access to essentials for survival, while there is an impressive body of international treaties dedicated to prohibiting the use of specific weapons. In this respect it is noteworthy that it is widely accepted that international humanitarian law applies to peace operations. ${ }^{107}$ In this sense international humanitarian law, with its emphasis on proportionality, discrimination and prohibited weapons, operates to minimise the adverse humanitarian impact of the use of force.

\footnotetext{
${ }^{101}$ Nigel S. Rodley, 'Collective Intervention to Protect Human Rights' cited in Wheeler (n 77) 35.

102 de Waal (n 75) 1051.

103 Ibid.

${ }^{104}$ Sloan (n 94) 386.

${ }^{105}$ Richard Falk, 'Hard Choices and Tragic Dilemmas' The Nation (20 December 1993)

${ }^{106}$ Bellamy, Just War (n 21) 124.

${ }^{107}$ See SG's Bulletin on 'Observance by United Nations Forces of International Humanitarian Law' UN Doc ST/SGB/1999/13.
} 
However, the principle of military necessity in conjunction with the doctrine of doubleeffect in the just war tradition permits the killing of non-combatants as 'unintended but foreseeable deaths'. ${ }^{108}$ In this connection Walzer argues that '[c]ivilians have a right to something more. And if saving civilian lives means risking soldier's lives, the risk must be accepted', concluding that '[w]e can only ask soldiers to minimise the dangers they impose' ${ }^{109}$. In this respect it is pertinent to note the two additional criteria to complement jus in bello in military interventions for human protection purposes identified by Bellamy, the first of which is due care in the selection of targets and weapons while the second concerns the selection of a military strategy that will 'achieve the best humanitarian outcome in the shortest amount of time and with the least danger to non-combatants'. ${ }^{110}$ It is in regards to the selection of military strategy, targets and weapons that a role may be accorded to international human rights law in providing a further layer of prudence in the use of force to protect civilians. ${ }^{111}$ For instance, the right to life, the prohibition on torture, inhuman or degrading treatment or punishment and the right to an adequate standard of living, including food, clothing, housing and medical care are especially relevant when selecting targets and weapons.

However, while it is generally accepted that international human rights law applies regardless of whether an armed conflict exists or not, ${ }^{112}$ the extent of that application is hotly contested in part due to the contested contours of the relationship with international humanitarian law. The dominant perspective to the relationship between international human rights and international humanitarian law is to consider international humanitarian law as lex specialis in circumstances of armed conflict. ${ }^{113}$ However, the ICJ recently acknowledged that there are three ways to conceive of the relationship between international human rights law and international humanitarian law namely, 'some rights may be exclusively matters of international humanitarian law; others may be exclusively matters of human rights law; yet others may be matters of

\footnotetext{
108 Walzer (n 49) 153.

109 Ibid 156.

${ }^{110}$ Bellamy, Just War (n 21) 213.

${ }^{111}$ For example, Kenneth Watkins, 'Controlling the Use of Force: A role for human rights norms in contemporary armed conflict’ (2004) 98 AJIL 1.

112 See Legality of the Threat or Use of Nuclear Weapons [1996] ICJ Rep 226, 240.

113 See Michael J. Dennis. 'ICJ Advisory Opinion on Construction of a Wall in the Occupied Palestinian Territory: Application of Human Rights treaties extra-territorially in times of armed conflict and military occupation' (2005) 99 AJIL 119, 141.
} 
both these branches of international law'. ${ }^{114}$ Nehal Bhuta calls this latter approach 'interpretative complementarity ${ }^{\prime 15}$ which is characterised by the use of international human rights law 'to inform and 'humanise' international humanitarian law while international humanitarian law is 'used to give content to [international human rights law] in certain exceptional states'. ${ }^{116}$ Kenneth Watkins, when discussing the control of the use of deadly force, adopts this understanding of the relationship between international human rights law and international humanitarian law as 'the issue should not be the exclusive application of either framework but, rather, that appropriate principles should be applied to ensure that there are no gaps in humanitarian protection'. 117

Viewing the relationship between international humanitarian law and international human rights law in this way offers a departure point from which to clarify the limits on the use of force to protect civilian populations. Such clarification is urgently required if human protection operations are to be successful in doing 'more good than harm'. Moreover, such current ambiguities are compounded by the practical reality that peace operations with a Chapter VII civilian protection mandate have been largely unsuccessful. ${ }^{118}$ In this regard it pertinent to note the words of caution issued in the Brahimi Report namely, '[i]f an operation is given a mandate to protect civilians, therefore, it also must be given the specific resources needed to carry out that mandate'. 119

\section{CONCLUding REMARKS}

The just war tradition as Bellamy observes 'is a two-thousand-year conversation about the legitimacy of war'. ${ }^{120}$ This article drew upon this long-standing and rich convention to assess and develop the guidelines for military intervention for human protection purposes and which provided a fruitful frame to analyse the roles of the SC and UN peace operations under the responsibility to react. For instance the just war tradition

\footnotetext{
${ }^{114}$ Legal Consequences of the Construction of a Wall in the Occupied Palestinian Territory [2004] ICJ Rep 156, 178.

${ }^{115}$ Nehal Bhuta, 'States of Exception: Regulating Targeted Killing in a 'Global Civil War' in Philip Alston and Euan MacDonald (eds) Human Rights, Intervention and the Use of Force (OUP 2008) 251.

116 Ibid 252.

${ }^{117}$ Watkins (n 111) 2.

${ }^{118}$ See Sloan (n 94).

${ }^{119}$ Report of the Panel on United Nations Peace Operations, (August 2000) para. 63.

${ }^{120}$ Bellamy, Just War (n 21) 2.
} 
re-frames the issue of legitimacy and authority plaguing the SC and offers an avenue by which to clarify the legal framework for UN peace operations. In doing so, the perspective brought to bear by the just war tradition illuminated a role for international law in guiding SC decision-making in respect of humanitarian crises especially when jus cogens norms are at issue, along with a role for international humanitarian law and international human rights law in regulating the use of force in Chapter VII civilian protection mandates. In addition, the guidelines for military intervention are strengthened by the role for international law illuminated by the just war tradition. For instance, as alluded to above, the reliance on public opinion to galvanise the SC to act is tempered by the role accorded to international law in SC decision-making which similarly counters the charge of indeterminacy levelled at the just cause threshold. In this way, the just war tradition breathes 'doctrinal, policy and institutional life, ${ }^{121}$ into this facet of the responsibility to protect.

Moreover, the just war tradition addressed the arguments as to SC discretion and abuse that prompted the removal of the guidelines for military intervention from the Outcome Document and thus underscores Alex de Waal's observation that the responsibility to protect, as presently articulated by the UN, is inadequately conceptualised. ${ }^{122}$ Moreover, the removal of the guidelines undermines the capacity of the UN to respond to 'genocide, war crimes, ethnic cleansing and crimes against humanity' 123 as too readily evidenced by the response to the crisis in Darfur discussed above. In the last analysis, to paraphrase the HLP, the UN having given birth to the responsibility to protect, has proven poorly equipped to implement it. ${ }^{124}$

\footnotetext{
${ }^{121} \mathrm{SG}$, 'Implementing' (n 15) para. 2.

${ }^{122}$ De Waal (n 75) 1054.

${ }^{123}$ Outcome Document (n 2) para. 139

${ }^{124}$ HLP (n 1) para 13.
} 